\title{
The First International Workshop to Marine and Anchialine Meiofauna in Lanzarote 2011
}

\author{
Alejandro Martínez ${ }^{1}$ \\ Received: 9 August 2019/Revised: 9 August 2019 / Accepted: 23 August 2019 / Published online: 25 October 2019 \\ (C) Senckenberg Gesellschaft für Naturforschung 2019
}

This special issue of Marine Biodiversity features eight articles that represent the results of the First International Workshop to Marine and Anchialine Meiofauna in Lanzarote. This scientific workshop, held between 4 and 20 October 2011, involved a comprehensive survey of the most representative marine and anchialine habitats around the island of Lanzarote. Marine sampling included seven sandy beaches of different hydrodynamic state, three open caves mostly containing mud and coarse sand, and four open subtidal stations with different kinds of sediments. Sampling in the anchialine water bodies focused on the three flooded sections of La Corona lava tube: Cueva de Los Lagos, Los Jameos del Agua lake, and Túnel de la Atlántida, the world's longest flood lava tube (Martínez et al. 2016). This last section includes Montaña de Arena, the only truly interstitial anchialine habitat known in the island, situated $750 \mathrm{~m}$ within the cave (Wilkens et al. 2009). Sampling along La Corona lava tube was accompanied by the inspection of two complexes of anchialine pools (Charcos de Luis and Charcos de Montaña Bermeja) and the anchialine wells at Los Agujeros saltworks.

This article is a contribution to the Topical Collection Interstitial and cave diversity in Atlantic oceanic islands.

Alejandro Martínez

amartinez.ull@gmail.com

1 Water Research Institute National Research Council, Verbania, Pallanza, Italy
The main scientific objectives of the workshop were (1) to provide a comprehensive checklist of the marine and anchialine meiofauna in the Atlantic oceanic island of Lanzarote, (2) to investigate the ecological and geographical correlates to species richness and endemism at regional and local scales, (3) to complete the inventory of the interstitial fauna from the Montaña de Arena, and (4) to formally describe some of the most representative interstitial and cave species. The first three objectives were treated in the first contribution to this special issue (Martínez et al. 2019). This publication shows the astoundingly rich diversity of meiofauna that we encountered, which included 239 species amongst annelids, cnidarians, gastrotrichs, gnathostomulids, heterobranch molluscs, nemerteans, platyhelminths, priapulids, and rotifers. Our analyses showed that the proportion of endemic species was lower in groups with a higher proportion of parthenogenetic species, while it was not significantly affected by body size and percentage of species with dispersal stages. Only annelids showed significantly higher number of endemic species in anchialine habitats, highlighting the resemblance between the interstitial fauna to Montaña de Arena and that found in the sea.

The forth objective was treated in the seven other papers included in this issue, which formally described 10 out of the 85 new species to science found during this workshop (Di Domenico et al. 2019; Worsaae et al. 2019a, 2019b; Todaro et al. 2019; Gobert et al. 2019; Scarpa et al. 2019a, 2019b). Some of these papers went beyond the goals of the workshop, as they included the description of 10 additional species from 
Fig. 1 Group picture with some of the participants at the First International Workshop on Marine and Anchialine

Meiofauna, Lanzarote 2011.

Upper row, from left to right, Tom Artois, Marco Curini-Galletti, Asrin Partavian, Kirsten

Kvindeberg, Enrique Domínguez, Diego Fontaneto; lower row:

Toon Hansen, Maikon Di

Domenico, Alejandro Martínez, M Antonio Todaro, Katrine

Worsaae, Luis E Cañadas, Suso Fontes, and Ralf Schoenemark

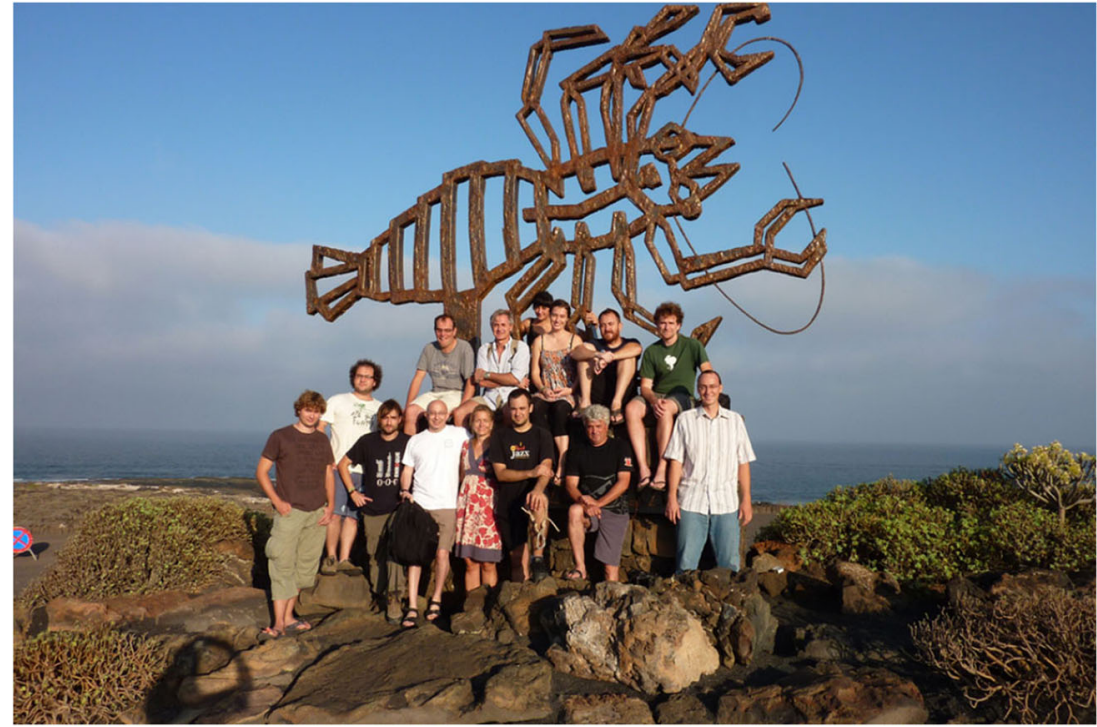

other geographical regions, as well as molecular studies on their phylogenetic relationships. In addition to the papers included in this volume, the material collected during the workshop has been published so far in a total of nine peer-reviewed scientific studies (Martínez et al. 2015, 2017, 2019; Leasi et al. 2016; Gonzalez et al. 2017a, b, 2018; Gusmão et al. 2016; Worsaae et al. 2018), and three book chapters (Martínez and Gonzalez 2018, Martínez et al. 2018, 2019).

The First International Workshop of Marine and Anchialine Meiofauna was organized by Alejandro Martínez and Katrine Worsaae (University of Copenhagen). It included scientists Tom Artois and Toon Hansen (Hasselt University); Marco Curini-Galletti (University of Sassari); Maikon Di Domenico (Federal University of Paraná); Diego Fontaneto (IRSA-CNR); Kirsten Kvindeberg, Peter R. Møller, and Asrin Partavian (University of Copenhagen); Francesca Leasi (University of Tennessee at Chattanooga); Jon Norenburg (Smithsonian Institution); and M Antonio Todaro (University of Modena) (Fig. 1); in addition to divers Luis Eduardo Cañadas, Enrique Domínguez, Sergio González, Carola D Jorge, Antonio Martín, Ralf Schoenemark, and Juan Valenciano (Fig. 2).
Fig. 2 Diving team by the entrance of Túnel de la Atlántida (from left to right): Antonio Martín, Juan Valenciano, Alejandro Martínez, Enrique Domínguez, and Carola D Jorge

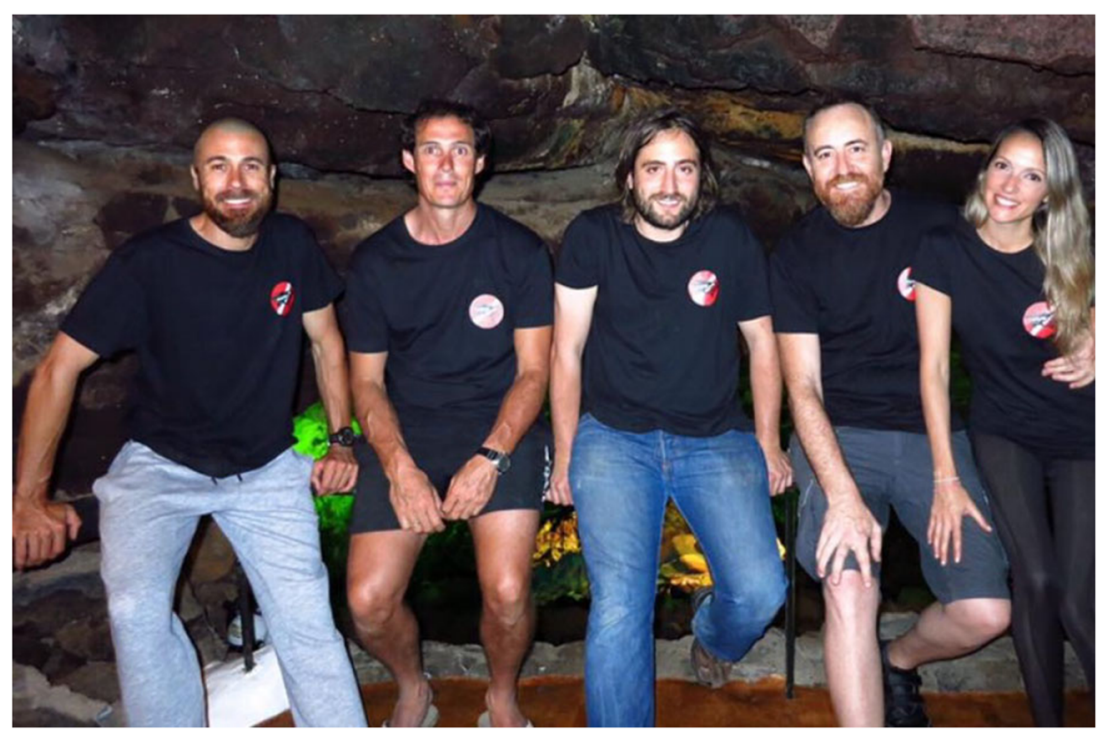


Acknowledgments I thank the local Environmental and Touristic Services of the Cabildo de Lanzarote for granting access to the Túnel de la Atlántida and for collection permits. My greatest gratitude goes to Elena Mateo and Clara Bonilla, currently working at Lanzarote and Chinijo Islands Global UNESCO Geopark, for their full support arranging the infrastructure for the workshop. Thanks to Leopoldo Moro Abad and Rogelio Herrera for helping us obtaining diving permits. I thank Suso Fontes for his help scheduling the dives at Los Jameos del Agua Touristic Centre, and providing his wonderful wine. Finally, I want to express my gratitude to all the divers and scientists who participated in the workshop, all showing their mastery and enthusiasm in obtaining the scientific results presented in this volume.

Funding information The organization of the workshop was funded by the Carlsberg Foundation in Denmark (2013_01_0779 to AM and CF 0946 and 2013010501 to $\mathrm{KW})$. AM was supported by Marie Skolodowska-Curie Individual Grant (IFEF, number 745530) during the writing of this volume. Partial funding for the expedition was from Reserva de la Biosfera and Consejería de Medio Ambiente of the Canary Government.

\section{Compliance with ethical standards}

Conflict of interest The author declares that he has no conflict of interest.

Ethical approval All applicable international, national, and/or institutional guidelines for the care and use of animals were followed.

Sampling and field studies All necessary permits for sampling and observational field studies have been obtained by the author from the competent authorities and are mentioned in the acknowledgements, if applicable.

Data availability There is no data associated with this manuscript.

\section{References}

Di Domenico M, Martínez A, Worsaae K (2019) Saccocirridae (Annelida) from the Canary Islands with descriptions of Saccocirrus slateri sp. nov. Mar Biodiv 49(5). https://doi.org/10. 1007/s12526-019-00991-7

Gobert S, Reygel P, Artois T (2019) Schizorhynchia (Platyhelminthes Rhabdocoela) of Lanzarote (Canary Islands), with the description of eight new species. Mar Biodivers 49(5). https://doi.org/10.1007/ s12526-017-0736-x

Gonzalez BC, Martínez A, Borda E, Iliffe TM, Fontaneto D, Worsaae K (2017) Genetic spatial structure of an anchialine cave annelid indicates connectivity within - but not between - islands of the Great Bahama Bank. Mol Phyl Evol 109:259-270

Gonzalez BC, Martínez A, Borda E, Iliffe TM, Eibye-Jacobsen D, Worsaae K (2018) Phylogeny and systematics of Aphroditiformia. Cladistics 34:225-259

Gusmão F, Domenico MD, Amaral ACZ, Martínez A, Gonzalez BC, Worsaae K, Ivar do Sul JA, Lana PC (2016) In situ ingestion of microfibres by meiofauna from sandy beaches. Environ Pollut 216:584-590

Leasi F, Andrade da S SC, Norenburg J (2016) At least some meiofaunal species are not everywhere. Indication of geographic, ecological and geological barriers affecting the dispersion of species of
Ototyphlonemertes (Nemertea, Hoplonemertea). Mol Ecol 25: 1381-1397

Martínez A, Gonzalez BC (2018) Volcanic anchialine habitats of Lanzarote. In: Moldovan O, Kováč L, Halse S (eds) Cave Ecology. Ecological Studies (Analysis and Synthesis), vol 235. Springer

Martínez A, Di Domenico M, Rouse GW, Worsaae K (2015) Phylogeny and systematics of Protodrilidae (Annelida) inferred with total evidence analyses. Cladistics 31:250-276

Martínez A, Gonzalez BC, Núñez J, Wilkens H, Oromí P, Iliffe TM, Worsaae K (2016) Guide to the anchialine ecosystems of Jameos del Agua and Túnel de la Atlántida. Medio Ambiente, Cabildo de Lanzarote, Arrecife, Lanzarote

Martínez A, Kvindebjerg K, Iliffe TM, Worsaae K (2017) Evolution of cave suspension feeding in Protodrilidae (Annelida). Zool Scr 46: 214-226

Martínez A, Purschke G, Worsaae K (2018) Handbook of zoology. Annelida. Protodrilidae Hatschek, 1888. p 38

Martínez A, García-Gómez G, García-Herrero A, Di Cesare A, Corno G, Herrera R, Moro L, Eckert EM, Fontaneto D (2019) Lanzarote and Chinijo Islands: An Anchialine UNESCO Global Geopark. In: Mateo E, Martínez-Frías J, Vegas J (eds) Lanzarote and Chinijo Islands Geopark: From Earth to Space. Geoheritage, Geoparks and Geotourism (Conservation and Management Series). Springer, Cham

Martínez A, Di Domenico M, Leasi F, Curini-Galletti M, Todaro MA, Dal Zotto M, Artois T, Norenburg J, Jörger KM, Núñez J, Fontaneto D, Worsaae K (2019) Patterns of diversity and endemism of soft-bodied meiofauna in an oceanic island, Lanzarote, Canary Islands. Mar Biodivers 49(5). https://doi.org/10.1007/s12526-019-01007-0

Scarpa F, Cossu P, Sanna D, Lai T, Casu M, Curini-Galleti M (2019a) New insights on the genus Otoplana Du Plessis, 1889 (Platyhelminthes: Proseriata), with description of two new species from the Canary Islands. Mar Biodivers 49(5). https://doi.org/10. 1007/s12526-017-0785-1

Scarpa F, Sanna D, Cossu P, Lai T, Casu M, Curini-Galleti M (2019b) How to achieve internal fertilization without a vagina: the study case of the genus Archilina Ax, 1959 (Platyhelminthes, Proseriata) from Canary Islands. Mar Biodivers 49(5). https://doi.org/10.1007/ s12526-018-0890-9

Todaro MA, Cesaretti A, Dal Zotto M (2019) Marine gastrotrichs from Lanzarote, with a description of a phylogenetically relevant species of Urodasys (Gastrotricha, Macrodasyida). Mar Biodivers 49(5). https://doi.org/10.1007/s12526-017-0747-7

Wilkens H, Iliffe TM, Oromí P, Martínez A, Tysall T, Koeneman S (2009) The Corona lava tube, Lanzarote: geology, habitat diversity and biogeography. Mar Biodivers 39:155-167

Worsaae K, Giribet G, Martínez A (2018) The role of progenesis in the diversification of the interstitial annelid lineage Psammodrilidae. Invertebr Syst 32:774-793

Worsaae K, Gonzalez BC, Kerbl A, Nielsen SH, Jørgensen JT, Armenteros M, Iliffe TM, Martínez A (2019a) Description and evolution of the stygobitic Speleonerilla nom. nov. (Nerillidae, Annelida) with description of three new species from anchialine caves in the Caribbean and Lanzarote. Mar Biodivers 49(5). https://doi.org/10.1007/s12526-018-0906-5

Worsaae K, Mikkelsen M, Martínez A (2019b) Description of six new species of Mesonerilla (Nerillidae, Annelida) and an emended description of $M$. intermedia Wilke, 1953, from marine and cave environments. Mar Biodivers 49(5). https://doi.org/10.1007/s12526019-00984-6

Publisher's note Springer Nature remains neutral with regard to jurisdictional claims in published maps and institutional affiliations. 